\title{
Gain from Regional Trade Integration: The Case of the Arab Countries
}

\author{
Abdullah Mohammed Al-Obaidan \\ Assistant Professor \\ College of Administrative Science \\ Department of Finance and Financial Institutions \\ Kuwait University, Kuwait.
}

( Received 28.8.1419H, and Accepted 21.7.1420H )

\begin{abstract}
Despite the recent increasing research focus on the impact of regional trade integration on economic development, which has been spurred by the improvement of existing regional trade relationship and the introduction of new regional economic cooperation schemes, few quantitative studies on the magnitudes of the efficiency effect of trade integration have been conducted. The current study extends the existing literature by providing a quantitative measure of the efficiency effect of regional integration in the Arab World. The paper studies the effect of regional trade integration in the context of a neoclassical production function. The empirical results suggest, ceteris paribus, that Arab countries can improve the technical efficiency of their physical stocks and human assets by approximately 14 percent simply by promoting regional trade integration among the countries in the region.
\end{abstract}

\section{INTRODUCTION}

In addition to the trend toward globalization, the world economy seems to be headed in the direction of regionalization. Members of the European Union (EU), for example, are devising a mechanism for attaining economic unity that will strengthen that giant trading bloc and have far-reaching implications for the world economy. The same can be said about the newly formed regional integration in North America resulting from implementation of the North America Free Trade Agreement (NAFTA). There are also indications that Southeast Asia and the Pacific Basin will see the birth of yet another giant trading bloc.

In the Arab World, regional economic cooperation and integration as a policy approach to economic development is not a new phenomenon. Various attempts have been made in the past to devise a formula to attain regional trade integration among the Arab countries. The dream of establishing the Arab Common Market is as old as the plans to establish the original European Economic Community. Economic 
integration among the Arab countries has been a principal goal of economic and political cooperation since the establishment of the Arab League toward the end of War World II. Arab countries have been able to utilize several channels, including both multilateral and bilateral trade agreements, to expand their inter-Arab trade integration. In practice, both the implemented trade agreements and the regional conflicts within the Arab World have resulted in great variations in inter-Arab trade.

The most fundamental incentive for regional trade integration is the expectation of net economic gain for the participating countries. Hence, the questions are raised of how much material gain the Arab countries have made, and how much this gain has been affected by its economic agreements. Certainly, changes in inter-Arab trade relations during the past two decades provide a unique opportunity to judge if the degree of inter-Arab trade integration has affected the economic progress of the member countries.

This study is organized as follows: A brief discussion of inter-Arab trade agreements is presented in Section II. The theoretical analysis of the benefit of regional trade integration is presented in Section III. Data and variable construction are analyzed in Section IV. Using the frontier production function, as more recently rigorously developed by Huang (1984, pp.847-56), Berger (1993, pp.261-92) and AlObaidan and Scully (1995, pp.231-38), the empirical results are presented in Section V suggesting that the greater the increase in inter-Arab trade integration, the greater the economic efficiency of the allocated resources in the Arab countries.

\section{INTER-ARAB TRADE AGREEMENTS}

At the international level, many Arab governments have willingly agreed to be members of the General Agreement on Tariffs and Trade (GATT) and the World Trade Organization (WTO $)^{(1)}$. This has resulted in the creation of a vehicle for promoting trade liberalization. In addition, closer economic integration among nation states in different regions has internationalized a range of policy domains that previously were either simply ignored, or considered an exclusively part of national sovereignty. Consequently, major multilateral initiatives have led to negotiations and in some cases agreements in new areas such as trade in services, the protection of intellectual property rights, and investment. Accordingly, many countries in the Arab world are obliged to adopt a multi-policy, comprehensive approach that should promote the openness of markets to both regional and global competition (For more details see Zarrouk, 1998, pp.9-45, and Sirageldin, 1998, pp.39-57).

On the other hand, at the regional level, trade agreements constitute the basis for preferential economic treatment among Arab countries. The existence of several trade agreements since the early fifties reflects the desire of Arab Governments to provide a means to enhance inter-Arab trade integration. Such agreements include the 1953

(1) The Arab countries which are members of the GATT are (date of accession in parentheses): Kuwait (May 1963), Egypt (May 1970), Morocco (June 1987), Tunisia (August 1990), Bahrain (December 1993), United Arab Emirates (UAE) (1994), Qatar (April 1994). On the other hand, Arab countries that have joined the WTO are: Bahrain, Djibouti, Egypt, Kuwait, Mauritania, Morocco, Qatar, Tunisia, and UAE, while other Arab countries have expressed interest in WTO membership which have so far held observer status in the WTO. For more details see Zarrouk, (December 1988, pp.9-45). 
Transit Trade Agreement to facilitate and organize transit trade as a preparatory phase to establish a common market among the Arab countries. The 1964 agreement among a group of Arab countries was intended to create a common market in stages to provide an advanced framework for inter-Arab trade promotion. Likewise, the Agreement for the Facilitation and Promotion of Trade among member states of the Arab League, signed in 1981, is a declaration of intent by the signatories to negotiate the elimination of tariff, non-tariff, and other taxes of similar effect for manufactured and semimanufactured goods. Moreover, the latest achievement in joint Arab economic integration endeavor is reflected in the Arab Trade Financing Program (ATFP), established in 1990 in recognition that financing inter-Arab trade is an essential factor in encouraging Arab exporters and importers to trade with each other on a continuous and regular basis.

In addition to seeking economic integration at both the international and the panArab levels, joint Arab trade efforts have attempted to liberalize inter-Arab trade through various channels. Such channels include multilateral trade agreements. The decade of the 1980s, for example, saw the rise of three subregional integration schemes: (1) the Gulf Cooperation Council (GCC), which includes six Arab countries (Bahrain, Kuwait, Oman, Qatar, Saudi Arabia, and the United Arab Emirates); (2) the Arab Cooperation Council, composed of four Arab countries (Egypt, Iraq, Jordan and Yemen); and (3) the Maghreb Economic Union, which includes five Arab countries (Algeria, Libya, Mauritania, Morocco, and Tunisia). Of the three subregional schemes, the GCC and the Maghreb Union are proceeding as planned in their founding agreements.

The signed trade agreements among the Arab countries were expected to allow Arab economies to achieve greater gains from increased trade. Historical evidence suggests, however, that the regional trade cooperation mode of the Arab countries has been greatly affected by the intensity of regional conflicts and the degree of political stability of the individual countries. Therefore, past decades witnessed great variations in the degree of regional trade integration in the Arab countries. Consequently, total inter-Arab trade varied from nearly \$2 billion in 1972 (International Monetary Fund, 1991 , p.65) to reach approximately $\$ 24$ billion in 1981 ; then it plunged to $\$ 13$ billion in 1986, and finally it increased to reach its record level of 1981 at the end of 1996 (Arab Monetary Fund, 1996-1997, p.14). The economic impact of inter-Arab trade variations may be magnified since it may be accompanied with discriminating conditions on labor mobility and capital flows (such flows may include investment, government assistance, and/or soft loans from regional development agencies) between Arab countries. Therefore, the degree of inter-Arab integration has consequences for the allocation of resources (efficiency) within the Arab economies.

\section{ECONOMIC EFFICIENCY OF TRADE INTEGRATION}

Regional economic integration means different things in different regions and at different times. In developing countries, regional integration is a tool for economic development (Jovanovic, 1992, pp.32-86). Particularly where countries are small and/or are characterized by relatively low incomes, joint or cooperative action is likely 
to be more effective in promoting new types of business activity than the separate actions of individual countries. Accordingly, in this paper, regional integration refers to the discriminatory removal of trade impediments between participating countries and the establishment of certain elements of coordination between them for the purpose of promoting regional trade integration (El-Agraa, 1985, pp. 93-111).

Viner (1950, pp.3-46) was the first to introduce the foundation for the theory of customs union, which represents the core of the theory of international economic integration. The theory suggests that the formation of a customs union encourages trade creation as the result of a change from a more expensive to a cheaper source of supply. Other things being equal, this is a move towards free trade because a less efficient, protected, domestic supplier is replaced by a more efficient foreign one. Trade diversion works in the opposite way from trade creation, whereby the cheapest foreign supplier is changed in favor of a relatively more expensive customs-union supplier. The important questions are, therefore: Which aspect of preferential trade arrangements is dominant? Is a particular trade arrangement trade diverting or trade creating? Viner's theory provoked an extensive theoretical discussion on additional consumption and production effects of customs unions and alternative assessment criteria, such as the market for a single good (Johnson, 1962, pp.5-76) versus all markets (Meade, 1968, pp.4-15; Riezman, 1979, pp.341-54; Berglas, 1979, pp.315-31; Lloyd, 1982, pp.41-63). Furthermore, the theory generated a wide range of issues that impact on the regional development question: the lack of sensitivity to geography by trade theorists (Grant, 1994, pp.298-312), externalities and the localization of industry (Krugman, 1991, pp.5-101，1993a, pp.110-22,1993b, pp.160-79), the role of history and the path of dependence (Krugman, 1990, pp.1-23), and the implications of economic and monetary integration for regional growth (Krugman 1993c, pp.241-69; Casella, 1993, pp.216-66). The result of this discussion was inconclusive. To the extent that small domestic markets constrain growth, however, regional integration is looked upon as an instrument to make such constraint less binding. When domestic markets prove to be too small to allow reaping the benefits of scale economies, formation of a regional market is seen as a way out of this impasse. Thus, the expectation of a net economic gain compared to the situation without integration is the most fundamental incentive for regional trade integration.

Economic gains from regional trade integration may take different forms. Promoting regional trade integration, for example, may encourage the expansion of a country's exportable goods that hold a relative technological advantage in their production. This expansion may motivate some firms to utilize the newly formed regional market, which has superseded the domestic market, to deploy production and marketing strategies that are global. Also, regional integration may permit the establishment of industries that, given the national market's dimension, would be feasible only at excessively high cost. Consequently, regional trade integration may have a long-term positive effect on economic efficiency and growth rates. The positive effect results from the interaction of several factors, including improved utilization of installed capacity and promotion of employment and investment.

The outstanding economic factor in most Arab countries is the underemployment of resources; therefore, it is possible to increase the production of some goods without 
decreasing the production of any others. Thus, the general expansion of aggregate demand resulting from regional trade integration among the Arab countries permits a more rational use of those productive resources that are underutilized. This expansion both affects the size and direction of new investments, and raises the technical efficiency of industries through both enhanced utilization of the nation's physical stock and human assets, and increased competition among member countries. Therefore, the theoretical research on regional trade integration suggests a positive relationship between the degree of regional trade integration and the magnitude of technical efficiency. Thus, a country is expected to enjoy greater technical efficiency when its regional trade integration is relatively high. Economic efficiency, as described in this paper, arises whenever the observed input ratio approaches the cost-minimizing input ratio.

\section{DATA AND VARIABLE CONSTRUCTION}

\section{Stochastic Specification}

The empirical measurement of technical efficiency is derived from the frontier production function, first introduced by Farrell (1957, pp.11-46), and more rigorously developed in recent years ${ }^{(2)}$. Technical inefficiency is the result of the systematic choice of a suboptimal production plan. Measurement of technical inefficiencies hinges on the ability to separate random errors from the systematic error component. This can be accomplished by specifying a particular distribution for the systematic error term. The stochastic frontier function utilizes a half-normal distribution under the assumption that technical inefficiency is an asymmetric and increasing, but never decreasing, cost component. In contrast, the distribution-free model notes that random errors should average out over time, leaving a systematic component assumed to be timeindependent. Both measures of inefficiencies were estimated with no difference in the conclusion.

\section{Stochastic Frontier Function}

A stochastic frontier function, as proposed by Aigner et al. (1977, pp.21-37), and as more rigorously developed by Huang (1984, pp.847-56), assumes that the observed frontier deviates from the efficient frontier by a random noise, $v_{i}$, and an inefficiency component, $u_{i}$. Thus, the observed frontier function is:

$$
\ln \mathrm{Q}_{\mathrm{i}}=\mathrm{f}\left(\mathrm{K}_{\mathrm{i}}, \mathrm{L}_{\mathrm{i}}\right)+\varepsilon_{\mathrm{i}}
$$

Where:

$$
\varepsilon_{i}=u_{i}+v_{i} \text {. }
$$

(2) The frontier function criterion is utilized in this study. The criterion associates the output of the country to its input. The calculated technical efficiency for each country in the sample is measured in terms of deviations from the best performance in a representative peer group. Thus, economic performance is evaluated in relative rather than an absolute basis. Therefore, the econometric models used in this study are more appropriate than statistical models such as analysis of variance method. The most important weakness of the statistical approach is that detailed information on each country in the sample cannot be calculated. On the other hand, the econometric models used in this study provide detailed information about the technical efficiency for each country in the sample. 


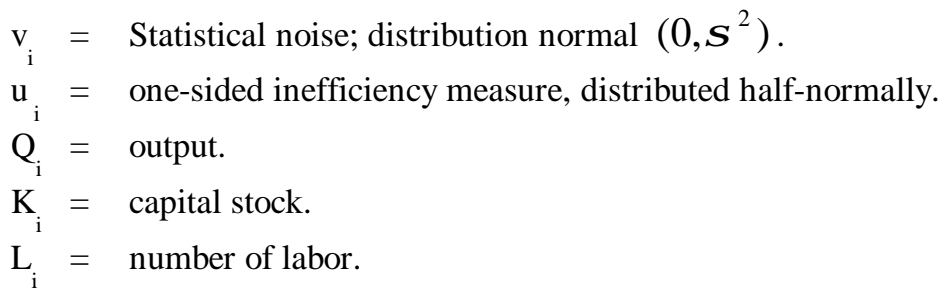

The log-likelihood function is given by:

$$
\ln \mathrm{L}=\frac{N}{2} \ln \frac{2}{\pi}-\mathrm{N} \ln \sigma-\frac{1}{2 \sigma^{2}} \sum_{i=1}^{N} \varepsilon_{i}^{2}+\sum_{i=1}^{N} \ln \left[\phi\left(\frac{\varepsilon_{i} \lambda}{\sigma}\right)\right]
$$

where $\mathrm{N}=$ number of countries. Jondrow et al. (1982, pp.233-38) shows that the ratio of variability can be used to measure a country's mean inefficiency, where $\sigma=\left[\sigma_{u}^{2}+\sigma_{v}^{2}\right], \lambda=\sigma_{u} / \sigma_{v}{ }^{\prime} \phi(\bullet)$ is the standard normal density function and is the standard normal cumulative distribution. Inefficiency measures are derived for all covered years for the complete sample as follows:

$$
E\left(u_{i} \backslash \varepsilon_{i}\right)=\left[\frac{\sigma \lambda}{1+\lambda^{2}}\right]\left[\frac{\phi\left(\frac{\varepsilon_{i} \lambda}{\sigma}\right)}{\Phi\left(\frac{\varepsilon_{i} \lambda}{\sigma}\right)}+\frac{\varepsilon_{i} \lambda}{\sigma}\right]
$$

\section{Distribution-Free Model}

Berger (1993, pp.261-92) avoids the strong distribution assumptions of the stochastic unit frontier function by introducing a distribution-free model. An advantage of this method is that it allows the coefficient to vary over time. The observed unit frontier equation is:

$$
\mathrm{Q}_{\mathrm{it}}=\mathrm{f}\left(\mathrm{K}_{\mathrm{it}}, \mathrm{L}_{\mathrm{it}}\right) \mathrm{u}_{\mathrm{t}} \mathrm{v}_{\mathrm{t}} \quad \mathrm{t}=1 \ldots \mathrm{T} \text {; }
$$

Thus, in this equation, $u_{t}$, the systematic error component, is a multiplicative inefficiency factor. Taking the logs, we obtain:

$$
\ln \mathrm{Q}_{\mathrm{it}}=\ln \mathrm{f}\left(\mathrm{K}_{\mathrm{it}}, \mathrm{L}_{\mathrm{it}}\right)+\ln \mathrm{u}_{\mathrm{t}}+\ln \mathrm{v}_{\mathrm{t}}
$$

where the variables are similar to those defined for equation (1). Only the $u_{t}$ remains fixed over time, while the rest of the coefficients and variables vary. For each country and time period, $t$, an average of the residuals for all covered periods is estimated, denoted $\ln u_{i}$. This average is an estimate of $\ln u_{t}$, assuming that random errors will cancel out over the covered periods. The estimated average residual is then transformed into a measure of inefficiency as follows:

$\operatorname{INEFF}_{i t}=\exp \left(\min \left(\ln u_{t}\right)-\ln u_{i t}\right)$

Where min $\left(\ln \mathrm{u}_{\mathrm{t}}\right)$ is the minimum $\ln \mathrm{u}_{\mathrm{it}}$ for the period of estimation $\mathrm{t}$. 


\section{Functional Specification}

Economies can be thought of as big firms. Just as the efficiency of firms is affected by increased sales, so is the efficiency of economies. Economies or nations have determined their regional trade integration status through a wide range of bilateral and multilateral agreements by which individual economic actors seek to utilize the prevailing trade opportunities. Increased regional trade integration has consequences for the allocation of resources (efficiency) in the economy.

Most empirical studies in the economic efficiency literature postulate a simple Cobb-Douglas production function ${ }^{(3)}$ of the following type for economy $\mathrm{i}$ at time $\mathrm{t}$ [see for example Goldar (1986, pp.23-64) Ahluwalia (1991, pp.6-63), Al-Obaidan and Scully (1995, pp.231-38) and Basant and Fikket (1996, pp.4-23) ] :

$$
\mathrm{Qe}^{\mathrm{f}(\mathrm{Q})}=\mathrm{AK}^{\alpha} \mathrm{L}^{1-\alpha}=\mathrm{A} \beta^{\alpha} \mathrm{L}, \mathrm{A}>0,1>\alpha>0, \beta=\mathrm{K} / \mathrm{L},
$$

where $\mathrm{Q}$ represents output; $\mathrm{K}$ and $\mathrm{L}$, respectively, represent the amounts of capital and labor inputs; and $\mathrm{A}$ and $\alpha$ are parameters. The function $\mathrm{f}(\mathrm{Q})$ is assumed to be a continuous convex function of $\mathrm{Q}$ with a minimum point for some positive $\mathrm{Q}$. Therefore, the function exhibits economies of scale up to $\mathrm{Q}$ followed by a range of diseconomies of scale. By dividing both sides of equation (4) by $\mathrm{L}$ and rearranging, the observed logged efficiency production function can be written in the intensive form as :

$$
\ln \gamma_{\mathrm{it}}=\ln \left(\mathrm{R}_{\mathrm{it}}\right)+\ln \mathrm{u}_{\mathrm{it}} \text {; }
$$

where $\gamma=\mathrm{Q} / \mathrm{L}, \mathrm{R}=\mathrm{K} / \mathrm{L}, \mathrm{u}_{\mathrm{it}}=$ one-sided inefficiency measure, and $\mathrm{Q}, \mathrm{L}$, and $\mathrm{K}$ are the national output, labor force, and capital stock, respectively.

The effect of an increase in the productivity of the capital-labor ratio on the productivity of real per capita gross domestic product depends on how resources are utilized in the economy. For equal rates of capital formation, economies that are able to utilize prevailing regional trade integration opportunities will enhance the productivity of their capital stocks and human assets. On the other hand, reduction or elimination of regional trade integration opportunities may lead to underutilization of the nations' capital stocks and human assets, which will lead to transforming inputs into output relatively inefficiently. One or more of the economies described by the neoclassical production function above will have values of output per capita during certain periods (increased regional trade integration opportunities) that are greater than other periods (reduction/elimination of regional trade integration opportunities) with similar values of the input ratio. These economies are the most technically efficient in transforming inputs into output. The study utilizes the inter-Arab trade variable to test the efficiency differences between economies resulting from differences in trade relations between the countries in the sample. Thus, the efficient frontier $\left(\gamma^{*}\right)$ of equation $(5)$ is written as:

$$
\ln \gamma^{*}{ }_{\text {it }}=f \ln \left(\mathrm{R}_{\mathrm{it}}\right)
$$

(3) The assumption is testable. A flexible production function was estimated. An F-test on the unrestricted model versus the restriction of unity for the sum of the coefficient yielded $F=0.20$, which is insignificant. 
Technical inefficiency $\left(u_{i t}\right)$ arises whenever the observed frontier $\left(\gamma_{\text {it }}\right)$ is less than the efficient frontier $\left(\gamma^{*}\right)$. As such, technical efficiency (TEM) can be measured as the ratio of $\gamma_{\text {it }} / \gamma^{*}$. Marginal efficiency becomes less than one whenever $\gamma^{*}>\gamma_{\text {it }}$ and it reaches a maximum of unity when technical inefficiency $u_{\text {it }}=0$ or $\gamma_{\text {it }}^{*}=\gamma_{\text {it }}$.

\section{Data and variables}

The cross-country economic data employed in this study comes from two sources: "National Accounts of Arab Countries" and "Foreign Trade of Arab Countries," both published by the Arab Monetary Fund. Data on gross domestic product (at factor cost in millions of U.S. dollars), total investment (in millions of U.S. dollars), and population was obtained from the "National Accounts of Arab Countries." Data on total inter-Arab trade (in millions of U.S. dollars) was obtained from "Foreign Trade of Arab Countries."

Regional trade integration status is determined after a thorough investigation of the nature and characteristics of inter-Arab trade patterns. First the inter-Arab trade data (exports and imports) for the period 1976-96 is examined. Naturally the data reflects the degree of regional economic cooperation/regional trade integration. The greater the inter-Arab exports and imports, the greater the regional trade integration. Second, the criterion of the regional trade integration status is determined. The mean value of the inter-Arab trade variable is calculated for each country in the sample for the period 1976-96. A relatively high regional trade integration period is judged to be the case if the inter-Arab trade variable of the country is greater than its calculated mean value. The use of population as a proxy for the labor force is disagreeable but conventional. The annual series of total investment is the capital stock used in this study.

A pooled cross-country and time series of 17 economies for the period 1976-96 (complete $\mathrm{N}=325$ ) is utilized in this study. Table (1) presents the countries in the sample along with the inter-Arab trade variable (in millions of U.S. dollars). The variable reflects large variations in inter-Arab trade volume, which is caused mainly by the degree of regional economic cooperation between the Arab countries. Using the mean value of the inter-Arab trade variable of each country in the sample as a cut-off point, 178 cases are defined to have high-degree regional trade integration status, and 147 cases are defined to have low-degree regional trade integration status.

Arab countries' economies differ in the degree of dependency on mining, quarrying, and fuel production activities. Analysis of variance tests revealed that the degree of dependency on these economic activities affected the capital and labor productivity of the economies in the sample. Since the objective of the study is to test the economic impact of regional trade integration, the effect of the degree of dependency on these economic activities must be neutralized. This is accomplished by introducing into the empirical analysis the following variable:

Mining, quarrying, \& fuel production (MQ\&F) ratio $^{(4)}=\mathrm{MQ} \& \mathrm{~F}$ in millions of U.S. dollars/GDP at market prices * 100

(4) The ratio is obtained from "National Accounts of Arab Countries 19976-1996", published by the Arab Monetary Fund, pp.21-165. 
Table (1) Total Inter-Arab Trade of the Countries in the Sample * ( millions of U.S. dollars )

\begin{tabular}{|l|c|c|c|c|}
\hline Country & 1981 & 1986 & 1991 & 1996 \\
\hline 1. Algeria & 156.42 & 185.30 & 405.20 & 507.20 \\
\hline 2. Bahrain & 3828.11 & 1832.10 & 2070.91 & 2419.42 \\
\hline 3. Egypt & 311.97 & 501.22 & 678.75 & 1165.79 \\
\hline 4. Emirates & 2350.90 & 1294.70 & 2107.90 & 3981.80 \\
\hline 5. Jordan & 1085.76 & 843.75 & 809.64 & 1676.35 \\
\hline 6. Kuwait & 2502.80 & 1014.10 & 57.00 & 245.00 \\
\hline 7. Libya & 200.30 & 235.70 & 886.00 & 1287.60 \\
\hline 8. Mauritania & 4.37 & 19.43 & 44.30 & 39.76 \\
\hline 9. Morocco & 1088.07 & 540.16 & 1344.28 & 1134.22 \\
\hline 10. Oman & 586.39 & 2089.12 & 1056.99 & 1470.06 \\
\hline 11. Qatar & 269.10 & 217.89 & 422.79 & 680.29 \\
\hline 12. Saudi Arabia & 7321.70 & 2745.10 & 5655.70 & 6374.10 \\
\hline 13. Somalia & 172.31 & 84.74 & 54.34 & 143.93 \\
\hline 14. Sudan & 560.45 & 262.20 & 343.76 & 666.12 \\
\hline 15. Syria & 1722.63 & 435.16 & 924.70 & 1214.34 \\
\hline 16. Tunisia & 665.37 & 365.48 & 671.28 & 1001.12 \\
\hline 17. Yemen & 1280.73 & 282.83 & N.A & N.A \\
\hline Total & 24107.38 & 12948.98 & 17533.54 & 24007.1 \\
\hline resulting from the civil war in Lebanon and the Iraq-Iran war. & & & \\
\hline
\end{tabular}

The MQ\&F ratio reflects the degree of the country's dependency on the economic activities that are used to construct the ratio. Countries that are totally dependent on the activities will have an MQ\&F ratio of 100. Countries that are not engaged in the activities will have a value of 0 . Countries that are engaged in the mentioned activities will fall in the interval of 0 to 100.

Besides differences in mining, quarrying, and fuel production activities, analysis of variance tests revealed that Arab countries differ in the level of exposure to external trade (other than inter-Arab trade). To ensure that this difference does not affect the empirical results, the following independent variable is introduced into the frontier equation:

Foreign trade exposure ratio $(\mathrm{FER})=$ total external trade in millions of U.S. dollars-inter-Arab trade in millions of U.S. dollars/total external trade in millions of U.S. dollars

The FER ratio reflects the country's exposure to foreign trade. Countries that are engaged in foreign trade will be in the interval of 0 to 100 . Naturally, the higher the exposure to foreign trade, the larger the FER ratio. 
Finally, the construction of a disaggregated production function containing variables that reflect economic factors that may influence the efficiency of the allocated national resources within the Arab countries in the sample (such as level of local competition, level of local technical skills, and relative input and output prices in the Arab countries) may be more appropriate than the aggregated production function (capital stock and labor) used here. Furthermore, the use of trade integration factor, which reflects not only inter-Arab trade variations, but also variations in the imposed discriminating conditions on labor mobility and capital flow between Arab countries, may be more appropriate than the trade integration proxy used here. However, microquantitative data of this sort is simply not available, and we proceed with caveats with the data that is available. Thus, the lack of internationally comparable time-series micro-data that can be utilized to neutralize some country-specific economic factors leads us to caution that the results of this empirical study should be viewed as suggestive, not definitive.

\section{EMPIRICAL RESULTS}

The estimated distribution-free frontier and the stochastic frontier function are presented in Table (2). The dependent variable is gross domestic product at factor cost in millions of U.S. dollars divided by labor. The independent variable is capital stock in millions of U.S. dollars divided by labor, the MQ\&F, and the FER ratios. The estimated frontier functions are statistically highly significant.

Table (2) Estimated Frontier Functions

\begin{tabular}{|l|c|c|c|c|c|}
\hline & \multicolumn{5}{|c|}{ Independent Variables Statistics } \\
\hline $\begin{array}{l}\text { Dependent Summary } \\
\text { Variable }\end{array}$ & $\begin{array}{c}\text { Constant } \\
\text { [t-statistics] }\end{array}$ & $\begin{array}{c}\text { Capital Stock/labor } \\
\text { [t-statistics] }\end{array}$ & $\begin{array}{c}\text { MQ\&F } \\
\text { [t-statistics] }\end{array}$ & $\begin{array}{c}\text { FER } \\
\text { [t-statistics] }]\end{array}$ & $\begin{array}{c}\text { Adj R-sq } \\
\text { F-value }\end{array}$ \\
\hline Distribution-free frontier & 1.231 & 0.978 & 0.006 & 0.111 & 0.964 \\
\hline Output/Labor & {$[8.340]$} & {$[31.905]$} & {$[1.752]$} & {$[5.493]$} & 1481 \\
\hline Stochastic frontier & & & & & Scale \\
\hline Output/Labor & 1.229 & 0.981 & 0.006 & 0.113 & 0.5477 \\
\hline & {$[8.425]$} & {$[32.280]$} & {$[1.732]$} & {$[5.477]$} & \\
\hline
\end{tabular}

a Variables are in logarithms.

The frontier functions in Table (2) are the basis for the estimates of technical efficiency (TEM). Technical efficiency is the dependent variable in the test of the effect of regional trade integration on efficiency in Table (3). The independent variable in the equation in Table (3) is a dummy variable that is equal to 1 for high-degree regional trade integration cases (trade integration) and 0 for low-degree regional trade integration cases. In both the distribution-free frontier approach and the stochastic frontier approach, the trade integration coefficient is positive and statistically highly significant. The statistical results suggest that technical efficiency is 0.064 points higher in high-degree regional trade integration cases than in low-degree regional trade integration cases for the distribution-free approach, and 0.065 points higher for the stochastic approach. Comparison of the average technical efficiency of the highdegree regional trade integration cases with that of the low-degree regional trade integration cases reveals that high-degree regional trade integration cases are 114 percent $([0.461+0.064] / 0.461=1.139) ;([0.463+0.065] / 0.453=1.140)$ as efficient as 
low-degree regional trade integration cases. Thus, ceteris paribus, Arab countries may increase the utility of their human assets and capital stocks by approximately 14 percent simply by promoting and enhancing regional trade integration.

Table (3) Estimates of the Effect of Inter-Arab trade Integration on Technical Efficiency

\begin{tabular}{|l|c|c|c|}
\hline & & Statistics & \\
\hline Functional specification & $\begin{array}{c}\text { Constant } \\
\text { [t-statistics] }\end{array}$ & $\begin{array}{c}\text { Trade Integration } \\
\text { [t-statistics] }\end{array}$ & $\begin{array}{c}\text { F-value } \\
{[\text { Prob>F] }}\end{array}$ \\
\hline Distribution-free frontier & 0.461 & 0.064 & 11.243 \\
\hline & {$[34.989]$} & {$[3.353]$} & {$[0.001]$} \\
\hline Stochastic frontier & 0.463 & 0.065 & 11.243 \\
\hline & {$[34.989]$} & {$[3.353]$} & {$[0.001]$} \\
\hline
\end{tabular}

\section{SUMMARY AND CONCLUSION}

Free trade and unimpeded movement of factors is the best policy in a world that has no distortion. This is only a hypothetical situation. The real world is full of market imperfections that may be corrected and/or exploited by the employment of economic policy. Thus, the rationale for regional trade integration is the existence of an imperfect international market. Accordingly, the most fundamental incentive for regional trade integration is the expectation of a net economic gain for the participating countries. Anticipated gains include increased efficiency in the use of national resources resulting from improved utilization of installed capacity, promotion of employment and investment, and increased competition. The magnitude of the economic gains from regional trade integration and the scope of mutually advantageous reallocation depend on many factors. Such factors include the diversity of the traders' preference and the countries' production factor endowments. The outstanding economic factor in the Arab World is the underemployment of resources. Thus, with a population of more than 130 million, enhancing regional trade integration among the Arab countries can open great opportunities to improve their economic welfare. The empirical evidence presented in this study provides an objective, quantitative measure of the benefit of promoting trade among the Arab countries. The empirical results suggest, ceteris paribus, that Arab countries can increase the technical efficiency of their physical stocks and human assets by approximately 14 percent simply by enhancing trade integration and strengthening economic cooperation among the countries in the region. As noted, the calculated technical efficiency of trade integration in the Arab World may be magnified, since it may reflect not only inter-Arab trade variations, but also variations in the imposed discriminating conditions on labor mobility and capital flow between Arab countries.

The results found here support the recent calls from officials in the Arab League to implement fully the trade agreements signed in 1964 and 1981 between members of that league to promote regional trade integration. Moreover, the findings support the more recent efforts by some foreign and regional leaders to promote regional economic cooperation among the countries in the region and other economic blocs, including the EU. Likewise, the current trends in the world economy that are fueling globalization and generating closer economic cooperation among nations, are intensifying pressure 
on policy makers in the Arab World to promote closer trade coordination among members of the Arab league. However, regional trade integration among the Arab countries is not very effective by itself unless national policies are addressed first. Such policies include adopting appropriate national financial and economic policies to promote a globally competitive private sector. This shall include the following factors: emphasizing a market-oriented economy, fiscal responsibility, a tax structure that encourages investment, financial liberalization (to promote saving and investment), export oriented growth, (with an appropriate exchange rate policy to promote manufacturing exports), appropriate credit expansion policies (to check inflation and avoid distortions), flexible labor markets, relatively uniform and declining tariffs (to reduce distortion and promote competition), more opportunities for the private sector, and privatization.

\section{References}

Ahluwalia, Isher, J. (1991), "Productivity and Growth in Indian Manufacturing", Oxford, Oxford University Press.

Aigner, D. J., Knox Lovell, C. A. and Schmidt, P., (1977) "Formulation and estimation of stochastic production models," Journal of Econometrics, vol. 6, pp. 21-37.

Al-Obaidan, Abdullah M. and Gerald W. Scully, (1995)“"The Theory and Measurement of the Net Benefits of Multinationality: The Case of the International Petroleum Industry". Applied Economics, vol. 27, pp. 231-38.

Arab Monetary Fund, (1976-1997) Foreign Trade of Arab Counties, Arab Monetary Fund, Economics and Technical Department, United Arab Emirates, PO Box 2818.

Arab Monetary Fund, (1976-1997) National Accounts of Arab Countries, Arab Monetary Fund, Economics and Technical Department, United Arab Emirates, PO Box 2818, pp.1-165.

Basant, Rakesh, and Brian Fikket (1996), "The Impact of R \& D, Technology Purchase, and Technology Spillovers on Indian Industrial Productivity: Some Tentative Estimates," Working Paper No. 12, United Nations University, Institute of New Technology, Maastricht.

Berger, A. N., (1993) "Distribution-free Estimates of Efficiency in the U.S. Banking Industry and Tests of the Standard Distributional Assumptions", Journal of Productivity Analysis vol. 4, pp. 261-292.

Berglas, E. (1979) "Preferential Trading Theory: The Commodity Case", Journal of Political Economy, pp. 315-31.

Casella, A. (1993) Discussion of Krugman's Lesson of Massachusetts for EMU, in Adjustment and Growth in the EMU, (Ed.) F. Torres; and F. Giavazzi, Cambridge: Cambridge University Press. pp. 261-66.

El-Agraa, A. (1985) "General Introduction", in The Economics of the European Community (ed. A. El-Agraa), Oxford : Phillip Allan, pp. 93-111.

Farrell, M. J. (1957), "The Measurement of Productive Efficiency," Journal of Royal Statistical_Society ${ }_{2}$ 120(3), pp. 11-48.

Goldar, B. N. (1986), "Productivity Growth in Indian Industry," Delhi: Allied Publishers.

Grant, R. (1994) “The Geography of International Trade", Progress in Human Geography, vol. 18, pp. 298-312.

Huang, C. J. (1984) "Estimation of Stochastic Frontier Production Function and Technical Inefficiency Via the EM Algorithm”, Southern Economic Review, vol. 50, pp. 847-56.

International Monetary Fund (1991) Direction of Trade Statistic Yearbook, International Monetary Fund Publication Services 700 19th street, N. W., Washington, D. C. 20431, USA.

Johnson, H. (1962) Money, Trade and Economic Growth, London: George Allen \& Unwin. 
Jondrow, J., C.A.K. Lovell, I. S. Materov and P. Schmidt, (1982) "On the Estimation of Technical Efficiency in the Stochastic Frontier Production Model", Journal of Econometrics, vol. 19, pp. 233-238.

Jovanovic, Miroslav N. (1992) International Economic Integration, Routledge, Chapman and Hall, Inc. 29 West $35^{\text {th }}$ street, New York, NY 10001.

Krugman, P. (1990) Rethinking International Trade, Cambridge: MIT Press. (1991) Geography and Trade, Leuven: Leuven University Press. (1993a) "On the Relationship Between Trade Theory and Location Theory," Review of International Economics, vol. 1, pp. 110-22.

(1993b) “The Current Case for Industrial Policy," In Protectionism and World Welfare, (ed.) D. Salvatore, Cambridge: Cambridge University Press. pp. 16079.

(1993c) “The Lessons of Massachusetts for EMU," in Adjustment and Growth in the European Monetary Union, (ed.) F. Torres; and F. Giavazzi, Cambridge: Cambridge University Press. pp. 241-69.

Lloyd, P. (1982) Theory of Customs Unions," Journal of International Economics, vol. 3, No.3, pp. 41-63.

Meade, J. (1968) The Pure Theory of Customs Unions, Amsterdam: North Holland Publishers.

Riezman, R. (1979) "Model of customs unions". Journal of International Economics, vol. 3, No. 3, pp. 341-54.

Sirageldin, Ismail (December 1998) "Globalization, Regionalization and Recent Trade Agreement: Impact on Arab Economies, "rapid exogenous change-slow endogenous response", Journal of Development \& Economic Policies, vol. 1, No. 1, pp.39-77.

Viner, J. (1950) The Customs Union Issue, London: Stevens \& Sons. Limited for Carnegie Endowment for International Peace.

Zarrouk, Jamaleddine, (December 1988) The State of Arab Trade Policies and their Prospects in Light of WTO's Agreements, Journal of Development \& Economic Policies, vol. 1, No. 1, pp.9-45. 
مكاسب التكامل التجاري الإقليمي : حالة الدول العربية

$$
\begin{aligned}
& \text { عبد الله محمد العبيدان } \\
& \text { أستاذ مساعد اله } \\
& \text { كلية العلوم الإدارية - قسم المال } \\
& \text { جامعة الكويت - الكويت }
\end{aligned}
$$

المستخلص :لعل من أهــم التطـورات الاقتصاديـة خـلال السـنوات القليلـة السـابقة الاهتمـام

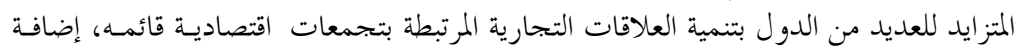

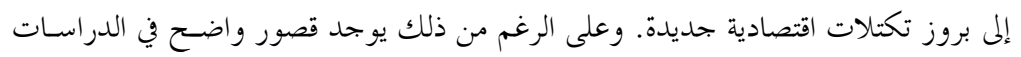

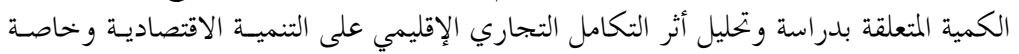

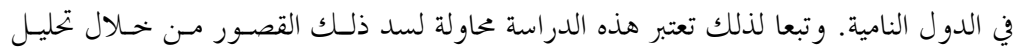

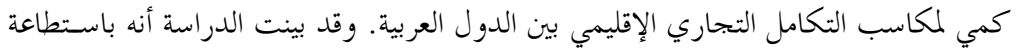

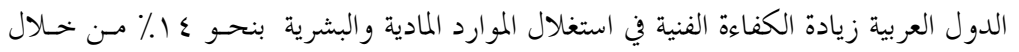

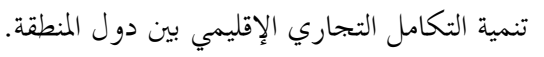

